\title{
Forage yield and nutritive value of Tanzania grass under nitrogen supplies and plant densities
}

\author{
Fabrício Paiva de Freitas ${ }^{1}$, Dilermando Miranda da Fonseca ${ }^{2}$, Thiago Gomes dos Santos \\ Braz $^{1}$, Janaina Azevedo Martuscello ${ }^{3}$, Manoel Eduardo Rozalino Santos ${ }^{4}$
}

\footnotetext{
1 Programa de Pós-graduação em Zootecnia/Universidade Federal de Viçosa, Viçosa-MG.

2 Departamento de Zootecnia/Universidade Federal de Viçosa, Viçosa-MG.

${ }^{3}$ Departamento de Zootecnia/Universidade Federal de Alagoas, Arapiraca-AL.

${ }^{4}$ Universidade Federal de Uberlândia, Uberlândia-MG.
}

\begin{abstract}
The objective of this experiment was to evaluate the nitrogen and plant density influence on the yield, forage dissection and nutritive value of Tanzania grass (Panicum maximum Jacq.). The design was of completely randomized blocks with three replications in a factorial arrangement with four nitrogen levels $(0,80,160$ or $320 \mathrm{~kg} / \mathrm{ha} \mathrm{N})$ and three plant densities $\left(9,25\right.$ or 49 plants $/ \mathrm{m}^{2}$ ). The plots were cut at $25 \mathrm{~cm}$ from soil level when the canopy reached $95 \%$ of light interception. The total dry matter forage yield and dry matter forage yield per harvest increased linearly with the nitrogen fertilization. The leaf and stem yield had the same response. The senesced forage yield was quadratically influenced by the nitrogen. The stems ratio in the morphologic composition was high in the high nitrogen levels and in the low plant densities. The leaf:stem ratio showed high values in this trial, but it was increased in plots without nitrogen and high plant density. The pre-grazing height was reduced with the increase in plant density. The nutritive value was favored by the nitrogen fertilization, which increased the crude protein level and reduced neutral detergent fiber and lignin. These factors increased the leaf and stem in vitro digestibility of organic matter. Nitrogen fertilization increases the forage yield of Tanzania grass under rotational grazing. After the establishment, plant density has little influence on the Tanzania grass yield and its forage dissection. The harvest with 95\% light interception improves the structure and nutritive value of Tanzania grass pastures
\end{abstract}

Key Words: fertilization, forage dissection, intermittent stocking, light interception, Panicum maximum, pasture management

\section{Introduction}

It is estimated that $22 \%$ of the national territory is occupied with pastures (IBGE, 2006), and that approximately $90 \%$ of the nutrients required by ruminants are originated from pasture (Euclides et al., 2010). However, the production indexes of Brazilian cattle farming are below its potential, probably due to the adoption of arbitrary measures at the management of pasture, such as stocking rate, grazing pressure, and mainly, number of regrowth days.

Due to the variations in the growth rates of pasture and the seasonality of production, the use of fixed grazing cycles, for example, may result in early or late harvesting, factors that impair growth and/or degrade the pasture structure (Voltolini et al., 2010). As an alternative to the traditional recommendations of managements, the concept of light interception established in the study of management of temperate forages may be also applied to the tropical forages (Hodgson \& Da Silva, 2002). Therefore, in systems of intermittent stocking, the pre-grazing condition in which the pasture intercepts $95 \%$ of the light corresponds to the maximum net growth of the forage plant. In addition to this, the latter presents structure and nutritional value that favor the intake of forage by animals (Carnevalli et al., 2006).

Notwithstanding, several factors can modify the competition for light, and consequently, productivity and structure of the canopy. In this sense, nitrogen has great capacity to modify the flow of tissues in tropical grasses, resulting in substantial increase in forage accumulation (Marschner, 1995). Thus, the application of nitrogen usually results in anticipation of the ideal pre-grazing condition, which must be followed by adjustments in the defoliation management (Fonseca et al., 2008).

On the other hand, little is known about the impacts of plant density on light intensity, especially when its effect is paired with nitrogen fertilization. It is likely that the density of plants at grazing may affect pasture structure by the change of tillering patterns, which may cause alterations in the capacity of biomass accumulation, and possibly, also in the relation between height and light interception. 
Therefore, the objective of this study was to verify the influence of nitrogen fertilization and plant density on productivity, structure and nutritive value of Tanzania grass under intermittent defoliation and 95\% light interception in pre-defoliation conditions.

\section{Material and Methods}

The experiment was conducted in an area pertaining to Setor de Forragicultura of the Departamento de Zootecnia of the Universidade Federal de Viçosa, in the period from October 2007 to April 2008. The city of Viçosa is located in the region called Zona da Mata Mineira, at 651 of height, with geographical coordinates $20^{\circ} 45^{\prime} 40^{\prime \prime} \mathrm{S}$ and $42^{\circ} 51^{\prime} 40^{\prime \prime}$ $\mathrm{N}$. The climate of the region, according to the classification proposed by Köppen (1948) is subtropical Cwa, characterized by mild, dry winter and rain and dry periods well-defined. The average annual rainfall is $1,340 \mathrm{~m}$; air humidity is $80 \%$; and average maximum and minimum temperatures are 27.3 and $14.9^{\circ} \mathrm{C}$, respectively. During the experimental periods, climate data were recorded (Figure 1).

The Tanzania grass (Panicum maximum Jacq.) was evaluated in $3 \times 3 \mathrm{~m}$ plots, established in December 2005, for studies at the initial growth stage of the forage, by Magalhães et al. (2011). Treatments were arranged in a $4 \times 3$ factorial arrangement, which corresponded to four doses of nitrogen $(0,80,160$ or $320 \mathrm{~kg} /$ ha.year $)$ and three plant densities $\left(9,25\right.$ or 49 plants $\left./ \mathrm{m}^{2}\right)$, totaling 12 treatments. The design was completely randomized blocks with three replicates. Blocks were established uprightly to the slope of the area.

The soil of the experimental area is classified as RedYellow Argisoil (EMBRAPA, 1999) of clayey texture. Before the beginning of evaluations (October, 2007), soil sampling was done at a depth of 0 to $20 \mathrm{~cm}$, and presented the following characteristics: $\mathrm{pH}$ in water $(1: 2.5$ ratio $)=5.88$; P-Mehlich ${ }^{-1}=2.25 \mathrm{mg} / \mathrm{dm}^{3} ; \mathrm{K}^{-M_{\text {Mehlich }}}{ }^{-1}=47 \mathrm{mg} / \mathrm{dm}^{3}$; $\mathrm{Ca}^{2+}=3.4 \mathrm{cmol}_{\mathrm{c}} / \mathrm{dm}^{3} ; \mathrm{Mg}^{2+}=0.88 \mathrm{cmol}_{\mathrm{c}} / \mathrm{dm}^{3} ; \mathrm{Al}^{3+}=$ $0 \mathrm{cmol}_{\mathrm{c}} / \mathrm{dm}^{3} ; \mathrm{H}+\mathrm{Al}=3.59 \mathrm{cmol}_{\mathrm{c}} / \mathrm{dm}^{3} ; \mathrm{V} \%=55 ; \mathrm{m} \%=0$; and $\mathrm{OM}$ (organic matter) $=1.67 \mathrm{dag} / \mathrm{kg}$. According to the results of this analysis, in November 2007, application of approximately $200 \mathrm{~kg} / \mathrm{ha} \mathrm{P}_{2} \mathrm{O}_{5}$ in the form of single superphosphate was performed on the plots of Tanzania grass.

The nitrogen doses were divided in three applications: the first one right after uniformity cutting, performed on November 2007; and the others, after the second and third cuttings in each plot (experimental unit). One hundred and fifty $\mathrm{kg} / \mathrm{ha} \mathrm{K}_{2} \mathrm{O}$ were also applied in two portions: one right

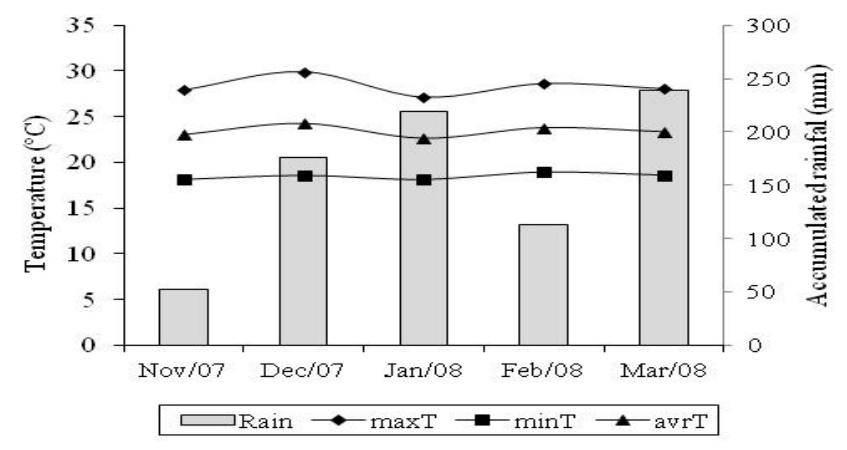

Source: Departamento de Engenharia Agrícola/UFV.

Figure 1- Accumulated monthly rainfall (Rain) and maximum (maxT), average (avrT) and minimum (minT) temperature values observed during the experimental period.

after uniformity cutting, and the second, after the second cutting in each plot. The sources of nitrogen and potassium were urea $(44 \% \mathrm{~N})$ and potassium chlorite $\left(58 \% \mathrm{~K}_{2} \mathrm{O}\right)$, respectively.

After uniformity cuttings, monitoring of the light interception was realized on the plots, through the system of canopy analysis SUNSCAN (Delta-T, Cambridge, England). Readings were done at every three days until readings reached value close to $90 \%$, and from this percentage daily, until reaching 95\% light interception, which was the moment when Tanzania grass was harvested, by picking a sample at $25 \mathrm{~cm}$ above the soil level per plot, in area delimited by a $0.78-\mathrm{m}^{2}$ rectangle. After sampling, the remainder from plants in the plots was mowed (backpack mower) at $25 \mathrm{~cm}$, and forage was removed from the area. Fresh samples, in laboratory, were divided in the morphological compounds leaf blades, pseudostems (stems + sheaths) and dead tissues. After drying, total production of leaf dry mass, pseudostem dry mass, dead tissue dry mass and percentages of leaves, pseudostem and dead tissue were quantified for estimation of total dry mass production. For the evaluation of variables total production of dry mass, leaf dry mass, pseudostem dry mass and dead tissue dry mass, the production accumulated over all the harvests above the remaining post- $25 \mathrm{~cm}$ cutting, as well as percentage of the morphological compounds were considered.

In each treatment, the number of harvests in the experimental period and the interval (days) of harvestings were recorded. Thus, production of dry mass per cutting was obtained by the quotient between production of dry mass and the number of harvestings performed in each experimental unit. 
Contents of crude protein (CP), neutral detergent fiber (NDF), lignin and in vitro organic matter digestibility (IVOMD) were estimated from the subsamples of blades and pseudostems through near-infrared reflectance spectroscopy, according to the procedures of Marten et al. (1985). The reflectance data of the samples of wavelength band from 1,100 to $2,500 \mathrm{~nm}$ were stored through spectrophotometer (Model NR5000: NIRSsystems, Inc., USA) attached to a desktop computer. Values of CP, NDF, lignin and IVOMD were obtained by calibration equations developed by conventional methods (Euclides \& Medeiros, 2003).

Canopy height was measured with scale graduated in centimeters, obtained by the average of five points of every experimental unit. The criterion utilized for the measuring of the height was based on the observation of the mean height of the leaf skyline on every measuring point.

The data were submitted to analysis of variance through the basic model:

$\mathrm{Y}_{\mathrm{ijkl}}=\mu+\mathrm{B}_{\mathrm{i}}+\mathrm{N}_{\mathrm{j}}+\mathrm{D}_{\mathrm{k}}+(\mathrm{ND})_{\mathrm{jk}}+\mathrm{e}_{\mathrm{ijkl}}$ in which: $Y_{i j k l}=$ observed value of the l-th repetition in the $k$-th level of $\mathrm{D}$, j-th level of $\mathrm{N}$ and $\mathrm{i}$-th level of $\mathrm{B}$; $\mathrm{B}_{\mathrm{i}}=$ effect of the $\mathrm{i}$-th level of block; $\mathrm{N}_{\mathrm{j}}=$ effect of the $\mathrm{j}$-th level of nitrogen; $D_{k}=$ effect of the k-th level of density; (ND) ${ }_{j k}=$ effect of the interaction of the $j$-th level of nitrogen and the k-th level of density; $\mathrm{e}_{\mathrm{ijkl}}=$ experimental error associated with the $\mathrm{Y}_{\mathrm{ijkl}}$ observation.

In the cases where there was no significance of the $\mathrm{N} \times$ D interaction, every factor was analyzed separately by means of regression, by being fitted to the most suitable model.

The data from light interception and height were adjusted according to the standard three-parameter exponential model, which showed most suitable for presenting deviations with homogeneous variance and normal distribution. Anticipating that the density of plants influenced the height at 95\% light interception, identity test of models (Regazzi, 2003) was carried out to assess the feasibility of adjusting of a single model capable of representing the variation of the data collected throughout the experiment.

All the statistical analyses were performed on the features PROC GLM, PROC REG and PROC NLIN from the software SAS (Statistical Analysis System), and 10\% was adopted as critical level of probability for type 1 error.

\section{Results and Discussion}

The duration of the interval of harvestings and number of harvestings were affected only by nitrogen
( $\mathrm{P}<0.05$ ), presenting quadratic and positive linear responses, respectively (Table 1 ).

At a dose of $320 \mathrm{~kg} / \mathrm{ha} \mathrm{N}$, plants were harvested, on average, 5.3 times, whereas in the absence of $\mathrm{N}$, there were 2.9 harvestings over the experimental period. This is a result from the effect of $\mathrm{N}$ increasing tissue flow (Braz et al., 2011) and the accumulation of biomass on the pasture, which anticipated the interception of $95 \%$ of light by the canopy, increasing, thus, the number of harvestings and decreasing their interval.

The harvesting interval varied from 24.5 with the $320-\mathrm{kg} / \mathrm{ha}$ $\mathrm{N}$ dose and 43 days in the absence of nitrogen fertilization. The shortest interval was estimated at 24 days, which corresponded to the estimated dose of $273 \mathrm{~kg} / \mathrm{ha} \mathrm{N}$. This stresses the great effect of $\mathrm{N}$ on the accumulation of forage and the need for raising the number of harvestings and, or grazing, once $\mathrm{N}$ also accelerates the senescence process, due to the self-shading of the canopy (Carnevalli et al., 2006; Barbosa et al., 2007; Da Silva et al., 2009).

The absence of effect of plants density on most of the variables evaluated (Tables 1 and 2) can be explained by the phenotypic plasticity of Tanzania grass. It is likely that the initial density difference, established during pasture formation, did not persist two years after seeding of the forage. Besides, the low intraspecific competition for light and nutrients on the plots established under low plant density might have favored the tillering of Tanzania grass, as observed by Braz et al. (2011). Consequently, there was compensation between the size and density of tussocks, so that plots established with low plant density presented higher tussocks, contrarily to what was verified at the units formed with high plant density. Such compensation, in spite of not being evaluated in the experiment, was observed in the experimental units and may have neutralized the effects of plant density on the total dry matter production, the structural and nutritive value characteristics of Tanzania grass. The positive effect of plant density on the production of Tanzania grass forage during the period of establishment observed by Magalhães et al. (2011) with shorter period of growth for plants to reach 95\% light interception, which resulted in greater number of harvestings in the more dense plots, corroborates this claim.

Total dry mass production presented positive linear response $(\mathrm{P}<0.01)$ to nitrogen fertilization and was not affected $(\mathrm{P}>0.10)$ by plant density or the interaction between these factors $(\mathrm{P}>0.10)$ (Table 1$)$. In the absence of nitrogen, the total dry mass was $750 \mathrm{~g} / \mathrm{m}^{2}$ and at the dose of $320 \mathrm{~kg} / \mathrm{ha}, 1,470 \mathrm{~g} / \mathrm{m}^{2}$, which stood for an increase of $96 \%$. The linear increase in total dry mass production caused by nitrogen may be explained by the fact that nitrogen is 
required in great amounts by the tropical climate forages, with great deposition of this nutrient in the zones of cell division (Gastal \& Nelson, 1994). Moreover, it is known that nitrogen fertilization increases the dry mass production of Panicum maximum, since nitrogen accelerates tissue flow, increases leaf length, appearance and development of tillers; factors that are positively related to forage production (Freitas et al., 2005; Martuscello et al., 2006; Braz et al., 2011).

The results obtained by Quadros et al. (2002), where nitrogen content increased linearly with forage production, corroborate the observed in the present study, which emphasizes the great potential of response of Tanzania grass to nitrogen. In this sense, França et al. (2007) also assessed production of Tanzania grass forage under three doses of N (200, 400 and $600 \mathrm{~kg} / \mathrm{ha}$.year) and irrigation, and obtained linear and positive response at 24.1; 27.7; and 34.9 t/ha.year of dry matter, respectively.

The total production of leaf blade dry mass presented positive liner response $(\mathrm{P}<0.01)$ to nitrogen fertilization (Table 1 ) and was not affected ( $P>0.10)$ by plant density or interaction between these factors $(\mathrm{P}>0.10)$. The increase generated by the application of $320 \mathrm{~kg} / \mathrm{ha} \mathrm{N}$ in relation to the absence of fertilization was $94 \%$. The greater total production of leaf blade dry mass is related to the higher number of harvesting observed in plants which received more $\mathrm{N}$. Defoliated plants more often tend to prioritize the recovery of photosynthetic apparatus, favoring, in this case, the accumulation of new leaves. Braz et al. (2011) observed greater leaf lengthening in Tanzania grass fertilized with $\mathrm{N}$, in the same experimental area, evaluating the same treatments.

With the harvesting of the forage with 95\% light interception, it was expected that the lengthening of the stem would be reduced, and hence, the dry mass of this morphological content as well. However, the total production of pseudostem dry mass was affected by nitrogen fertilization $(\mathrm{P}<0.10)$, which enabled a $166 \%$ increase in this variable, with the application of $320 \mathrm{~kg} / \mathrm{ha} \mathrm{N}$ (Table 1 ). This result is due to the greater lengthening of the Tanzania grass stem fertilized with nitrogen (Braz et al., 2011), which may be associated to the fast recovery of the canopy after cutting of the fertilized plants. The increase in stem lengthening was also observed by Martuscello et al. (2006) in Massai grass (Panicum maximum cv. Massai) fertilized with up to $240 \mathrm{~kg} / \mathrm{ha} \mathrm{N}$.

Total production of dead tissue dry mass was affected quadratically by $\mathrm{N}(\mathrm{P}<0.01)$, with no effects observed of plant density or interaction between factors $(\mathrm{P}>0.10)$ (Table 1). The greater accumulation of dead tissue, equivalent to $22.6 \mathrm{~g} . \mathrm{m}^{-2}$, was also estimated for the $196-\mathrm{kg} / \mathrm{ha}$

Table 1 - Regression equation, coefficient of variation (CV) and determination of variables intervals of harvesting, number of harvestings, total production of dry mass (TPDM), leaf blade dry mass (LBDM), pseudostem dry mass (PSDM) and dead tissue (DTDM) on Tanzania grass fertilized with nitrogen

\begin{tabular}{|c|c|c|c|}
\hline Variable & Equation & CV (\%) & $\mathrm{R}^{2}$ \\
\hline Number of harvestings & $\hat{\mathrm{Y}}=2.91+0.0076 * \mathrm{~N}$ & 34.3 & 0.95 \\
\hline $\operatorname{LBDM}\left(\mathrm{g} / \mathrm{m}^{2}\right)$ & $\hat{\mathrm{Y}}=707.83+2.0813 * \mathrm{~N}$ & 28.6 & 0.93 \\
\hline $\operatorname{PSDM}\left(\mathrm{g} / \mathrm{m}^{2}\right)$ & $\hat{\mathrm{Y}}=34.73+0.1892 * \mathrm{~N}$ & 59.7 & 0.85 \\
\hline
\end{tabular}

Table 2 - Regression equation, coefficient of variation (CV) and determination of the variables crude protein content in leaf blade $\left(\% \mathrm{CP}_{\mathrm{LB}}\right)$ and pseudostem $\left(\% \mathrm{CP}_{\mathrm{PS}}\right)$; content of neutral detergent fiber in leaf blade $\left(\% \mathrm{NDF}_{\mathrm{LB}}\right)$ and pseudostem $\left(\% \mathrm{NDF}_{\mathrm{PS}}\right)$; in vitro organic matter digestibility of leaf blade $\left(\% I V O M D_{L B}\right)$ and pseudostem $\left(\% I V O M D_{\mathrm{PS}}\right)$; and content of lignin in leaf blade $\left(\% \operatorname{Lig}_{\mathrm{LB}}\right)$ in Tanzania grass fertilized with nitrogen

\begin{tabular}{|c|c|c|c|}
\hline Variable & Equation & CV (\%) & $\mathrm{R}^{2}$ \\
\hline$\% \mathrm{CP}_{\mathrm{LB}}$ & $\hat{\mathrm{Y}}=8.19+0.0266 * \mathrm{~N}$ & 21.2 & 0.98 \\
\hline$\% C P_{P S}$ & $\hat{\mathrm{Y}}=4.54+0.0090 * \mathrm{~N}$ & 26.9 & 0.99 \\
\hline$\% \mathrm{NDF}_{\mathrm{LB}}$ & $\hat{\mathrm{Y}}=72.59-0.0376 * \mathrm{~N}+0.000058 * \mathrm{~N}^{2}$ & 2.8 & 0.89 \\
\hline$\% \mathrm{NDF}_{\mathrm{PS}}$ & $\hat{\mathrm{Y}}=74.18-0.0136 * \mathrm{~N}$ & 2.2 & 0.99 \\
\hline$\% I V O M D_{L B}$ & $\hat{\mathrm{Y}}=57.68+0.0437 * \mathrm{~N}$ & 7.8 & 0.94 \\
\hline$\% \operatorname{Lig}_{\mathrm{LB}}$ & $\hat{\mathrm{Y}}=3.03-0.0012 * \mathrm{~N}$ & 10.2 & 0.75 \\
\hline
\end{tabular}


$\mathrm{N}$ dose. This response is probably related to the higher number of cuttings occurring with the higher doses of $\mathrm{N}$, which enabled greater accumulation of senescent leaf tissues, especially at the base of the canopy. On the other hand, the deficiency of $\mathrm{N}$ may have limited the development of the canopy of non-fertilized plants, which retarded the beginning of the senescence process. Carnevalli et al. (2006) observed smaller accumulation of dead tissue on Mombaça grass (Panicum maximum Jacq. cv. Mombaça) at earlier stage of development (95\% light interception).

The production of dry mass per cutting was affected by doses of $\mathrm{N}(\mathrm{P}<0.10)$ and by plant density $(\mathrm{P}<0.10)$ (Figure 2$)$. Nitrogen provided linear increases in the production of dry mass per cutting, and the application of $320 \mathrm{~kg} / \mathrm{ha} \mathrm{N}$ resulted in only $10 \%$ increase when compared with the absence of its application. This slight increase indicates that the Tanzania grass managed under 95\% light interception at pre-cutting responds to the increase in the level of nitrogen, mostly through the increase in the number of defoliation cycles (Table 1) and keeping the forage mass per cycle almost constant. Thus, at the end of the period of utilization, greater total production of dry mass occurs (Table 1).

Plant density affected production of dry mass per cutting linearly and negatively, in such a way that the reduction in production of dry mass per cutting, caused by the increase in plant density from 9 to 49 plants $/ \mathrm{m}^{2}$, was of $13 \%$. This response can be attributed to the little reduction in the canopy height at 95\% light interception observed in the plots established with greater density. As canopy height is, in general, positively related to its forage mass (Pedreira et al., 2005), the decrease in production of dry mass per cutting with the elevation in plant density can be explained (Figure 2).

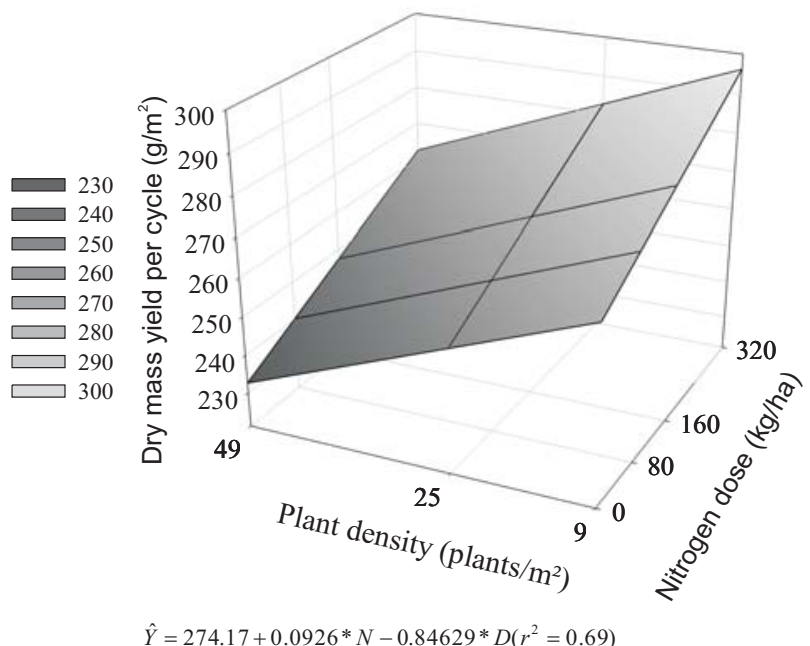

Figure 2 - Production of dry mass per cutting of Tanzania grass in function of nitrogen $(\mathrm{N})$ doses and plant densities.
In this sense, Carnevalli et al. (2006) also observed little variation in forage mass of Mombaça grass at pre-grazing condition, where values between 4.3 and $4.8 \mathrm{t} /$ ha.year was observed in the canopies grazed with $95 \%$ light interception and lowered up to $30 \mathrm{~cm}$ of residue.

Concerning the morphological composition of the forage, no effects were observed $(\mathrm{P}<0.10)$ on the factors evaluated regarding percentage of leaf blades and percentage of dead tissue. On the other hand, percentage of pseudostems was affected linear and positively $(\mathrm{P}<0.10)$ by nitrogen fertilization and negatively by plant density (Figure 3 ). The mean percentages of leaves and dead tissue in the forage dry mass were 93.4 and $1.6 \%$, respectively. Thus, the management adopted, with plant harvesting at 95\% light interception, decreased the accumulation of dead tissue and favored the accumulation of leaf blades, as shown in other studies (Carnevalli et al., 2006; Barbosa et al., 2007).

The increase in plant density reduced the participation of stems in the morphological composition of the forage, with values $4.7 ; 4.1$ and 3.1\% observed at densities 9, 25 and 49 plants $/ \mathrm{m}^{2}$, respectively (Figure 3 ). This result can be explained by the size/density compensation of the tillers, where, on the pastures with greater density of tussocks, tillers were lowers, which resulted in lower percentage of pseudostems in the canopy. On the contrary, at lower density of plants, tussocks are higher, and tillers are heavier, which favors the increase in the percentage of stems. Magalhães et al. (2011) also observed reduction in the percentage of stems with the density of Tanzania grass plants increase.

The application of nitrogen increased the percentage of stems (Figure 3), once this nutrient is important for the accumulation of biomass, including the accumulation of

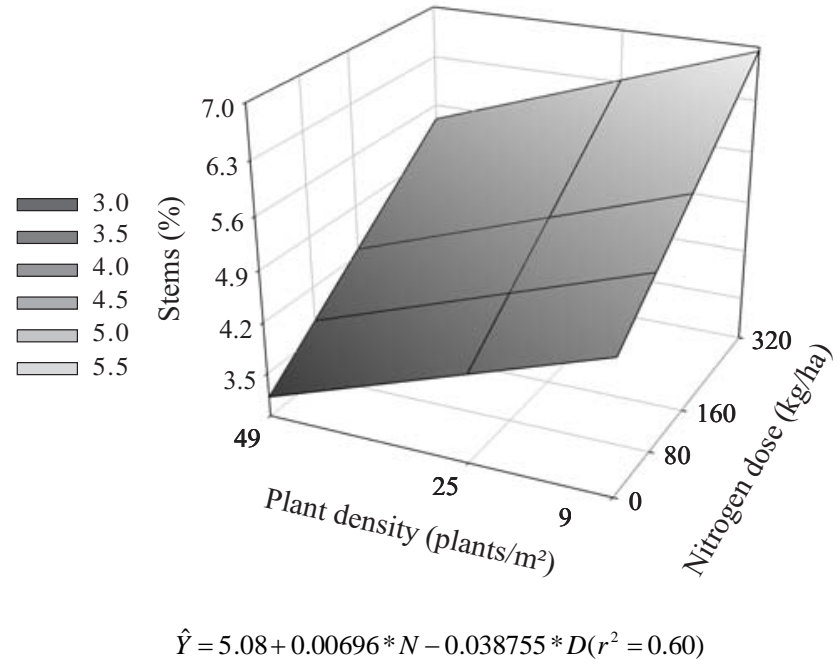

Figure 3 - Percentage of Tanzania grass stem in function of nitrogen $(\mathrm{N})$ doses and plant densities. 
stems, which was $44 \%$ higher at plants fertilized with $320 \mathrm{~kg} / \mathrm{ha}$, in relation to those not fertilized. The higher percentage of stems on the pastures under higher $\mathrm{N}$ doses can also be explained by the acceleration of the development of the canopy fertilized with $\mathrm{N}$, which increases the shadowing of tillers, which, in turn, respond to this condition through the increase in both stem lengthening and senescence. This way, the importance of adequate managing of grazing, such as the pre-defoliation criterion corresponding to the condition in which the canopy intercepts $95 \%$ of light must be emphasized, in order to reduce the relative participation of the stem in the forage produced on pastures fertilized with elevated $\mathrm{N}$ doses.

The accumulation of stems is, usually, undesirable, due to the increase of energy for the growth and maintenance of this fraction, which, in addition to hampering the adequate and uniform lowering of pastures when animals are utilized for the harvesting of the forage (Carnevalli et al., 2006), reduces the nutritive value of the forage produced (Santos et al., 2008). The increase in stem length also alters the distribution of leaves, which, in turn, modify the quality and quantity of light that penetrates in the canopy, reverberating directly on tillering, on the leaf area index (LAI) and on the accumulation of dry mass (Da Silva, 2004).

Yet, the absence of effects from nitrogen fertilization and plant density on the percentage of dead tissue can be explained by the management technique adopted, with plant harvesting at 95\% light interception, which inhibited senescence of tissue and plant organs (Carnevalli et al., 2006; Barbosa et al., 2007).

Canopy height at 95\% light interception was not affected by nitrogen fertilization $(\mathrm{P}>0.10$, although effect of plant density $(\mathrm{P}<0.10)$ could be observed, with no interaction between these factors ( $\mathrm{P}>0.10)$ (Figure 4 ).

The treatments with lower densities provided greater height at $95 \%$ light interception. The mean height for the treatment of 9 plants $/ \mathrm{m}^{2}$ was $66 \mathrm{~cm}$ (Figure 4A); for the treatment with 25 plants $/ \mathrm{m}^{2}$, it was $65 \mathrm{~cm}$ (Figure 4B); and $64 \mathrm{~cm}$ for the treatments with 49 plants $/ \mathrm{m}^{2}$ (Figure 4C). These results are opposite to those observed by Magalhães et al. (2011), during the establishment of Tanzania grass, where there was increase in height as plant density increased.
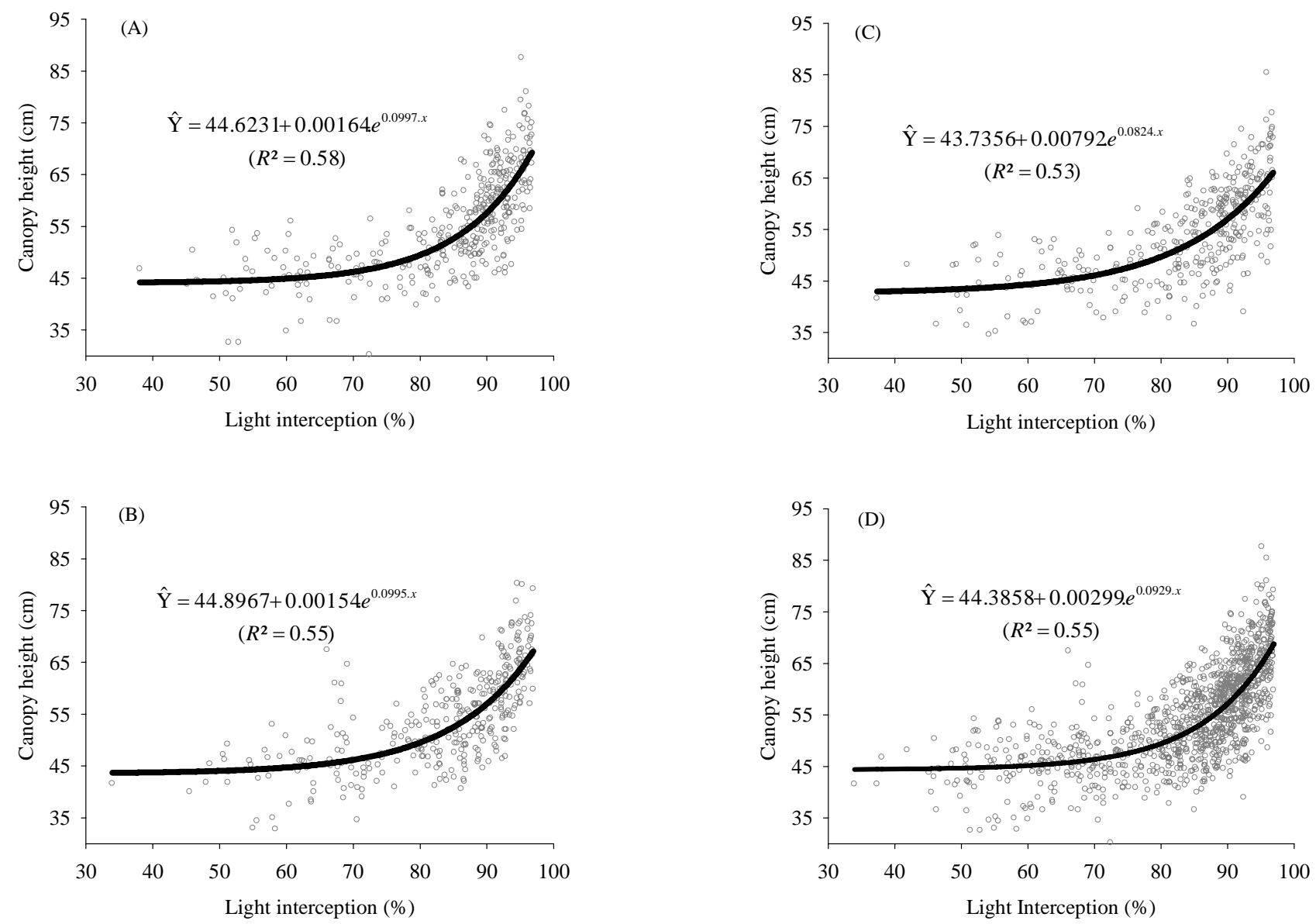

Figure 4 - Relationship between light interception and height in Tanzania grass harvested at 95\% light interception at the density of 9 plants $/ \mathrm{m}^{2}$ (A); 25 plants $/ \mathrm{m}^{2}$ (B); 49 plants $/ \mathrm{m}^{2}$ (C); and the model adjusted for all the densities (D). 
The author attributed this effect mostly to the straighter growth of the tillers in relation to what was observed at lower plant densities, situation in which the development occurred almost parallel to the soil surface. This difference in the effects of density stresses the variation in the Tanzania grass canopy structure after the establishment of the forage. This can be explained by the fact that the canopies with higher number of plants present greater leaf proportion and are distributed in order to facilitate light interception, which causes the aim of the management (light interception at 95\%) to be reached more quickly, hence with lower height. In this case, the change in the canopy architecture may have been responsible for the $95 \%$ light interception in lower heights for the treatments with greater plant density.

The differences observed, although statistically significant $(\mathrm{P}<0.10)$, were too little and could also be attributed to the natural variability of height of plants in the same pasture. In this sense, at the test of models identity performed for the three plant densities, there was no rejection $(\mathrm{P}>0.10)$ of the hypothesis of equality between the parameters of the models, which allowed the clustering of data in a single model (Figure 4D). In light of this new adjusted model, one can observe that the Tanzania grass reached 95\% light interception with approximate height of $65 \mathrm{~cm}$, a value that is slightly inferior to those obtained in other studies (Barbosa et al., 2007; Mello et al., 2004). According to Da Silva (2004), the 95\% interception in the incoming radiation on Tanzania grass occurs with $70 \mathrm{~cm}$ of height, regardless of the time of the year and the phenological stage of the plant. However, this value was not observed in the present study. Therefore, new research studies ought to be carried out to test the hypothesis that nitrogen fertilization and plant fertility can modify the relationship between light interception and canopy height.

The leaf blade/stem ratio was affected by nitrogen doses $(\mathrm{P}<0.05)$, plant density $(\mathrm{P}<0.10)$ and the interaction between the factors $(\mathrm{P}<0.10)$. The higher values of blade/ stem ratio were observed in plots established under height plant densities and lower nitrogen doses, or even not fertilized (Figure 5).

The increase in the leaf blade/stem ratio caused by the rise in density can be explained by the tillers length/density ratio, where the plots under higher densities present lower tillers and tussocks, and hence greater leaf blade/stem ratio. At lower densities, tillers and tussocks are longer, which decreases the leaf blade/stem ratio.

Overall, plants fertilized with lower $\mathrm{N}$ doses presented greater leaf blade/stem ratio, especially when established at higher densities. The increase in leaf blade/stem ratio in such conditions may be associated to the effect of nitrogen deficiency on the retardation of the development of the canopy, aggravated by the competition between plants established under higher densities. According to Cruz \& Boval (1999), deficiency of nitrogen reduces stem elongation of forage plants. Besides, the light interception-based management may result in harvesting of plants with favorable leaf blade/stem ratio. In fact, the leaf blade/stem ratio observed for the treatments evaluated was high, with the lowest leaf blade/stem ratio (11.95) estimated for the highest plant density associated to the highest nitrogen dose (Figure 5), which could be explained by the big competition for light that occurred in these plots.

Barbosa et al. (2007) observed greater amount of stems in the Tanzania grass plots defoliated with light interception superior to $95 \%$ and attributed the decrease in leaf blade/ stem ratio to the greater self-shading of the plants. Similar results were found by Carnevalli et al. (2006) and Gomide et al. (2007), where the leaf blade/stem ratio of Mombaça grass decreased as the canopies exceeded 95\% light interception.

As for the nutritive value of Tanzania grass, the content of crude protein (CP) in the leaf blade and in the stem presented positive linear response $(\mathrm{P}<0.01)$ to the nitrogen fertilization, but were not affected by plant density $(\mathrm{P}>0.10)$ or by the interaction between these factors (Table 2). In the absence of $\mathrm{N}$, the $\mathrm{CP}$ content in the leaf blade was $8 \%$, whereas in the doses of 80,160 and $320 \mathrm{~kg} / \mathrm{ha} \mathrm{N}$, the CP contents were 10,12 and $16 \%$, respectively. Concerning the stem, at the doses of $0,80,160$ and $320 \mathrm{~kg} / \mathrm{ha}$, the CP contents were $4.5 ; 5.3 ; 6.0$ and 7.4 , respectively, which corresponds to $64 \%$ increase in the greater dose applied in relation to the absence of fertilization.

The harvesting of Tanzania grass with 95\% light interception may have contributed to the production and

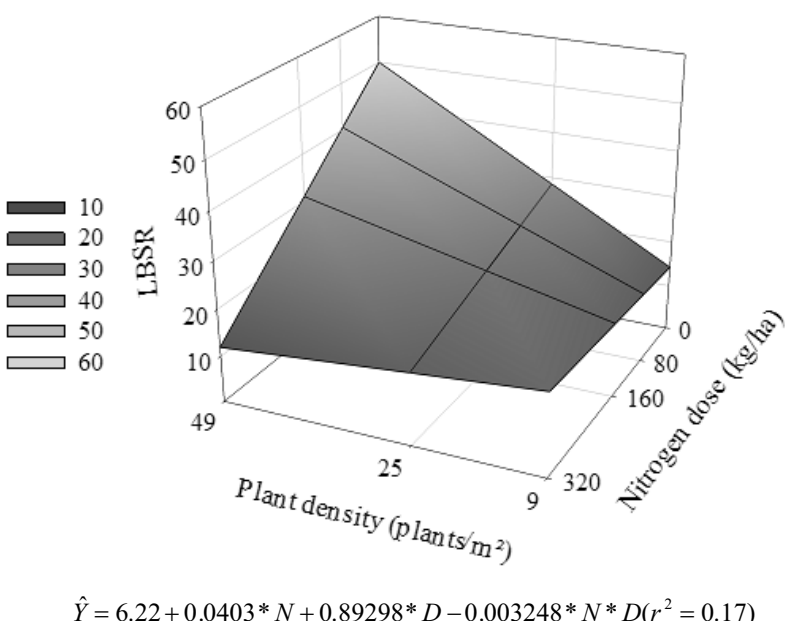

Figure 5 - Leaf blade/stem ratio (LBSR) in Tanzania grass in function of nitrogen $(\mathrm{N})$ doses and plant densities. 
harvesting of plants at a lower age and, consequently, greater protein content (Santos et al., 2008). In addition to this, the greater availability of nitrogen in the soil results in better absorption by the plant and higher concentration in the plant tissue. In this sense, Sousa et al. (2010) also observed positive effect in fertilization on the protein content of Tanzania grass, which responded quadratically to the fertilization, with values of 8.6 and $11.8 \%$ crude protein for the non-fertilized plots and fertilized with $300 \mathrm{~kg} / \mathrm{ha} \mathrm{N}$, respectively.

The effect of nitrogen fertilization on the nutritive value of the forage is dependent on the management of the pasture. In general, the pastures fertilized and under fixed periods of rest do not have their nutritional value characteristics enhanced by the application of $\mathrm{N}$ due to, among other factors, the effect of dilution of the nutrients that occurs in function of the increase in forage production per grazing cycle. On the other hand, when pastures are managed with $95 \%$ light interception as a criterion to start the grazing period (variable periods of rest), it is expected that the nutritive value of the forage will benefit from the $\mathrm{N}$ fertilization, because plants tend to be harvested at similar phenological stage and younger during the harvesting cycles (Fonseca et al., 2008). Regarding the management, this means that the optimal point for harvesting, when the best nutritive quality of the pasture is obtained, has a short duration, demanding, thus, more attention and observation in the use of paddocks.

The neutral detergent fiber (NDF) content in the leaf blade presented quadratic response $(\mathrm{P}<0.01)$ in function of the $\mathrm{N}$ doses (Table 2), but was not affected by plant density $(\mathrm{P}>0.10)$ or by the interaction between these factors $(\mathrm{P}>0.10)$. The lowest NDF content of the leaf blade (69.3\%) was estimated for the $324-\mathrm{kg} / \mathrm{ha} \mathrm{N}$ dose, which is equivalent to an $8 \%$ reduction in relation to the absence of $\mathrm{N}$ fertilization. It is likely that the $\mathrm{N}$ application resulted in higher leaf appearance rate, as observed by Braz et al. (2011), a situation in which the synthesis of shorter leaf blades on tropical grasses is common (Braz et al., 2010). These shorter leaf blades need lower proportion of structural tissues for their support and/or leaf architecture, which could explain their lower NDF contents. Linear reduction in the NDF content of the Tanzania grass forage was observed by Sousa et al. (2010), who found contents of 75.9; 74.0; 74.0 and $72.2 \%$, for the doses of $0,100,200$ and $300 \mathrm{~kg} / \mathrm{ha}$ of $\mathrm{N}$, respectively.

The NDF content of the stem responded linearly and negatively $(\mathrm{P}<0.01)$ only to nitrogen fertilization (Table 2$)$. It can be observed that the NDF content in the stems was superior to that of the leaves, because stems are structures responsible for the support of the plant organs.
The in vitro digestibility of the organic matter (IVDOM) of leaf blades $(\mathrm{P}<0.01)$ and stems $(\mathrm{P}<0.05)$ was affected only by nitrogen fertilization, presenting linear and positive responses (Table 2). The increase in the $I V D O M$ of the leaf blade and the stem with the application of the $320 \mathrm{~kg} / \mathrm{ha} \mathrm{N}$ dose, in relation to the absence of its application, was 24 and $12 \%$, respectively. The \%IVDOM of the leaf blade varied from $57.7 \%$ in the nonfertilized plants to $71.7 \%$ in those fertilized with $320 \mathrm{~kg} / \mathrm{ha}$ $\mathrm{N}$, and the \%IVDOM of the stem varied from 54.9 to $61.4 \%$ in those plants non-fertilized and fertilized with $320 \mathrm{~kg} / \mathrm{ha}$ $\mathrm{N}$, respectively. Such results can be explained either by the increase in the $\mathrm{CP}$ content or by the reduction in NDF content observed with the nitrogen fertilization. The higher $\mathrm{CP}$ content plays important role in the growth factor for the rumen microorganisms which present greater capacity of fermenting the plant cell wall (Van Soest, 1994). Therefore, the increase in the IVDOM of the leaf blade and the stem can also be attributed to the lower NDF contents of the leaf blade and the stem. In this sense, Toro-Velásquez et al. (2010) observed higher IVDOM of Tanzania grass at younger regrowth, with mean value of $50 \%$ for the rainy period.

The lignin content in the leaf blades was affected by the nitrogen fertilization, presenting negative linear response $(\mathrm{P}<0.05)$ (Table 2$)$. In the absence of $\mathrm{N}$, the lignin content in the leaves was $3.03 \%$, while at the $320 \mathrm{~kg} / \mathrm{ha} \mathrm{N}$ dose, it was $2.65 \%$. On the other hand, the lignin content in the stem was not affected by the factors in study $(\mathrm{P}>0.10)$

The reduction in the content of lignin in the leaf blade caused by the application of $\mathrm{N}$ may be associated with the increase in the cutting frequency for those plants more fertilized. In this condition, plants are harvested at younger ages and, additionally, the leaves remaining below the cutting height $(25 \mathrm{~cm})$ have less time to develop, which also contributes to their lower lignin content.

The lignin content in the Tanzania grass forage was low, which emphasizes the advantage of the management based on the 95\% light interception pre-defoliation for the production of forage with higher nutritive value.

\section{Conclusions}

With harvestings at 95\% light interception, nitrogen fertilization increases forage production and the nutritive value of Tanzania grass under intermittent defoliation. After the establishment stage, plant density has little influence on productivity and the morphological composition of the Tanzania grass. Tanzania grass presents $65 \mathrm{~cm}$ height when defoliated with 95\% light interception. 


\section{References}

BARBOSA, R.A.; NASCIMENTO JÚNIOR, D.; EUCLIDES, V.P.B. et al. Capim-tanzânia submetido a combinações entre intensidade e freqüência de pastejo. Pesquisa Agropecuária Brasileira, v.42, n.3, p.329-340, 2007.

BRAZ, T.G.S.; FONSECA, D.M.; FREITAS, F.P. et al. Morphogenesis of Tanzania guinea grass under nitrogen doses and plant densities. Revista Brasileira de Zootecnia. v.40, n.7, p.1420-1427, 2011.

BRAZ, T.G.S.; SANTOS, M.E.R.; GOMES, V.M. et al. Interdependência entre características do fluxo de tecidos do capim-braquiária. Enciclopédia Biosfera, v.6, n.10, p.12, 2010.

CARNEVALLI, R.A.; DA SILVA, S.C.; BUENO, A.A.O. et al. Herbage production and grazing losses in Panicum maximum cv. Mombaça under four grazing managements. Tropical Grasslands, v.40, p.165-176, 2006.

CRUZ, P.; BOVAL, M. Effect of nitrogen on some morphogenetical traits of temperate and tropical perennial forage grasses. In: INTERNATIONAL SYMPOSIUM "GRASSLAND ECOPHYSIOLOGY AND GRAZING ECOLOGY”, 1999, Curitiba. Proceedings... Curitiba: Universidade Federal do Paraná, 1999. p.134-150.

DA SILVA, S.C. Understanding the dynamics of herbage accumulation in tropical grass species: the basis for planning efficient grazing management practices. In: SYMPOSIUM ON GRASSLAND ECOPHYSIOLOGY AND GRAZING ECOLOGY, 2., 2004, Curitiba. Proceedings... Curitiba: Universidade Federal do Paraná, 2004. (CD-ROM).

DA SILVA, S.C.; BUENO, A.A.O.; CARNEVALLI, R.A. et al. Sward structural characteristics and herbage accumulation of Panicum maximum cv. Mombaça subjected to rotational stocking managements. Scientia Agricola, v.66, n.1, p.8-19, 2009.

EMPRESA BRASILEIRA DE PESQUISA AGROPECUÁRIA EMBRAPA. Centro Nacional de Pesquisa de Solos. Sistema brasileiro de classificação de solos. Rio de Janeiro, 1999. $412 \mathrm{p}$.

EUCLIDES, V.P.B.; MEDEIROS, S.R. Valor nutritivo das principais gramíneas cultivadas no Brasil. Campo Grande: Embrapa Gado de Corte, 2003. 43p. (Documentos, 139).

EUCLIDES, V.P.B.; VALLE, C.B.; MACEDO, M.C.M. et al. Brazilian scientific progress in pasture research during the first decade of XXI century. Revista Brasileira de Zootecnia, v.39, p.151-168, 2010 (supl. especial).

FONSECA, D.M.; SANTOS, M.E.R.; MARTUSCELLO, J.A. Adubação de pastagens no Brasil: uma análise crítica. In: SIMPÓSIO SOBRE MANEJO ESTRATÉGICO DA PASTAGEM, 4., Viçosa, MG. Anais... Ubá: Suprema Editora, 2008. v.1, p.295-334.

FRANÇA, A.F.S.; BORJAS, A.L.R.; OLIVEIRA, E.R. et al. Parâmetros nutricionais do capim-tanzânia sob doses crescentes de nitrogênio em diferentes idades de corte. Ciência Animal Brasileira, v.8, n.4, p.695-703, 2007.

FREITAS, K.R.; ROSA, B.; RUGGIERO, J.A. et al. Avaliação do capim mombaça (Panicum maximum Jacq.) submetido a diferentes doses de nitrogênio. Acta Scientiarum.Agronomy, v.27, n.1, p.83-89, 2005

GASTAL, F.; NELSON, C.J. Nitrogen use whitin the growing leaf blade of tall fescue. Plant Physiology, v.105, p.191-197, 1994.

GOMIDE, C.A.M.; GOMIDE, J.A.; ALEXANDRINO, E. Características estruturais e produção de forragem em pastos de capim-mombaça submetidos a períodos de descanso. Pesquisa Agropecuária Brasileira, v.42, n.10, p.1487-1494, 2007.

HODGSON, J.; DA SILVA, S.C. Options in tropical pasture manegement. In: REUNIÃO ANUAL DA SOCIEDADE BRASIlEIRA DE ZOOTECNIA, 39., 2002, Recife. Anais... Recife: Sociedade Brasileira de Zootecnia, 2002. (CD-ROM).

INSTITUTO BRASILEIRO DE GEOGRAFIA E ESTATÍSTICA IBGE. Available at: < http://www.ibge.gov.br/home/presidencia/ noticias/noticia_visualiza.php?id_noticia $=1064 \& i d$ _pagina $=1>$ Accessed on Mar. 30, 2008.

KÖPEN, W. Climatologia. Buenos Aires: Gráfica Panamericana, 1948. 478p.

MAGALHÃES, M.A.; MARTUSCELLO, J.A.; FONSECA, D.M. et al. Influência da irrigação, da densidade de plantio e da adubação nitrogenada nas características morfogênicas, estruturais e de produção do capim-tanzânia. Revista Brasileira de Zootecnia, v.40, n.11, p.2308-2317, 2011.

MARSCHNER, H. Mineral nutrition of higher plants. 2.ed London: Academic Press, 1995. 889p.

MARTUSCELLO, J.A.; FONSECA, D.F.; NASCIMENTO JÙNIOR, D. et al. Características morfogênicas e estruturais de capim-massai submetido a adubação nitrogenada e desfolhação. Revista Brasileira de Zootecnia, v.35, n.3, p.665-671, 2006.

MELLO, A.C.L.; PEDREIRA, C.G.S. Respostas Morfofisiológicas do capim-Tanzânia (Panicum maximum Jacq. cv. Tanzânia-1) irrigado à intensidade de desfolha sob lotação rotacionada. Revista Brasileira de Zootecnia, v.33, n.2, p.282-289, 2004.

MARTEN, G.C.; SHENK, J.S.; BARTON, F.E. Near infrared reflectance spectroscopy (NIRS), analysis of forage quality. Washington: USDA, ARS, 1985. 110p.

PEDREIRA, C.G.S.; ROSSETO, F.A.A.; DA SILVA, S.C. et al. Forage yield and grazing efficiency on rotationally stocked pastures of 'Tanzania-1' guineagrass and 'Guaçu' elephantgrass. Scientia Agricola, v.62, p.433-439, 2005.

QUADROS, D.G. ; RODRIGUES, L.R.A.; FAVORETTO, V.; et al. Componentes de produção de forragem em pastagens dos capins Tanzânia e Mombaça adubados com quatro doses de NPK. Revista Brasileira de Zootecnia, v.31, n.3, p.1333-1342, 2002 (supl.).

REGAZZI, A.J. Teste para verificar a igualdade de parâmetros e a identidade de modelos de regressão não linear. Revista Ceres, v.50, n.287, p.9-26, 2003.

SANTOS, M.E.R.; FONSECA, D.M.; EUCLIDES, V.P.B. et al. Valor nutritivo da forragem e de seus componentes morfológicos em pastagens de Brachiaria decumbens diferida. Boletim da Indústria Animal, v.65, n.4, p.303-311, 2008.

SOUSA, R.S.; PIRES, A.J.V.; CARVALHO, G.G.P. et al. Composição química de capim-tanzânia adubado com nitrogênio e fósforo. Revista Brasileira de Zootecnia, v.39, n.6, p.1200-1205, 2010.

TORO-VELÁSQUEZ, P.A.; BERCHIELLI, T.T.; REIS, R.A. et al. Composição química, fracionamento de carboidratos e proteínas e digestibilidade in vitro de forrageiras tropicais em diferentes idades de corte. Revista Brasileira de Zootecnia, v.39, n.6, p.1206-1213, 2010.

VAN SOEST, P.J. Nutritional ecology of the ruminant. 2.ed. Corvalis: O \& B Books, 1994. 374p.

VOLTOLINI, T.V.; SANTOS, F.A.P.; MARTINEZ, J.C. et al Características produtivas e qualitativas do capim-elefante pastejado em intervalo fixo ou variável de acordo com a interceptação da radiação fotossinteticamente ativa. Revista Brasileira de Zootecnia v.39, n.5, p.1002-1010, 2010. 